\title{
A candidate stem-group rossellid (Porifera, Hexactinellida) from the latest Ordovician Anji Biota, China
}

\author{
Joseph P. Botting, Yuandong Zhang \& Lucy A. Muir
}

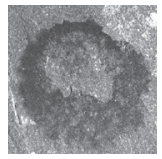

\begin{abstract}
The living hexactinellid sponge family Rossellidae is characterised by hypodermal pentactine prostalia and reduction of hexactins to diactins in irregular choanosomal spicule strands. The fossil record of this family extends back to the Upper Cretaceous ( $\sim 88 \mathrm{Ma}$ ), consistent with molecular-clock analyses that predict an origin at approximately $150 \mathrm{Ma}$. Herein we describe Matteolaspongia hemiglobosa gen. et sp. nov., one of the most abundant species in the latest Ordovician (444 Ma) Anji Biota of the Wenchang Formation, Zhejiang Province, South China. The biota preserves a relatively deep-water, sponge-dominated community from shortly after the end-Ordovician extinction. The new species described here possesses both hypodermal pentactine prostalia and a body wall including diactins, with an overall rossellid-like skeletal arrangement. However, differences from crown-group (extant) rossellids suggest either convergent evolution of the key characters, or a stem-group rossellid affinity for the new genus. Key words: sponge, Ordovician, Konservat-Lagerstätte, Lyssacinosida.
\end{abstract}

Botting, J.P., Zhang, Y. \& Muir, L.A. 2018. A candidate stem-group rossellid (Porifera, Hexactinellida) from the latest Ordovician Anji Biota, China. Bulletin of Geosciences 93(3), 275-285 (4 figures), Czech Geological Survey, Prague. ISSN 1214-1119. Manuscript received February 8, 2018; accepted in revised form June 7, 2018; published online July 19, 2018; issued August 20, 2018.

Joseph P. Botting, Nanjing Institute of Geology and Palaeontology, 39 East Beijing Road, Nanjing 210008, China \& Department of Natural Sciences, Amgueddfa Cymru - National Museum Wales, Cathays Park, Cardiff CF10 3LP, UK・ Yuandong Zhang, CAS Key Laboratory of Economic Stratigraphy and Palaeogeography, Nanjing Institute of Geology and Palaeontology and Center for Excellence in Life and Paleoenvironment, Chinese Academy of Sciences, 39 East Beijing Road, Nanjing 210008, China; ydzhang@nigpas.ac.cn • Lucy A. Muir, Department of Natural Sciences, Amgueddfa Cymru - National Museum Wales, Cathays Park, Cardiff CF10 3LP, UK

The Anji Biota is a latest Ordovician Konservat-Lagerstätte in Zhejiang Province, China (Botting et al. 2017a). The assemblage represents a relatively deep-water postextinction community (mid to late Metabolograptus persculptus Biozone) that was dominated by planktonic graptolites and a hyper-diverse assemblage of sponges, over 75 species as estimated on material available so far, with only rare examples of other taxa. This assemblage is now known to be part of a wider sponge-dominated community across South China (Li et al. 2015, Botting et al. 2018), the full extent and diversity of which remains to be discovered.

Some of the Anji Biota sponges are of significant phylogenetic interest, including an intermediate between the classes Hexactinellida and Demospongeae (Botting et al. 2017b). The majority of the sponge fauna is being described monographically, with additional taxa of particular interest described in shorter papers. This manuscript describes one of the most abundant species within the Anji Biota, which has implications for the recognition of the ancestors of the important modern family Rossellidae (Hexactinellida, Lyssacinosida; see Tabachnick 2002). The species is one of a suite of related taxa in the Anji Biota collections (most known from single or few specimens) that comprise a group with no other obvious representatives in the described fossil record. One species is described in detail here to provide a basis for future work on this group, which, based on preliminary collections at other sites, appears to be widespread within at least the Hirnantian deposits of South China.

Recognising hexactinellids in the fossil record has been widely assumed to be straightforward (e.g. Krautter 2002), due to the restriction of hexactine spicules and their derivatives to this class among modern sponges. However, this is now known not to be reliable, with hexactins being present in the stem lineages of probably all classes, and Porifera as a whole (Botting \& Muir 2018). Recognising the base of the crown group of Hexactinellida is particularly challenging, as there has been little information on the shared derived characters 
of the class, or the morphology of their last common ancestor. Recent attempts to characterise these earliest hexactinellids by character mapping onto molecular phylogenies (Dohrmann et al. 2017) have produced some limited success, with many ambiguities remaining. In general, recognition of crown-group hexactinellids in fossil assemblages relies on being able to place the fossil into an extant subgroup unambiguously, but this relies on close similarity to modern taxa, and has proven very difficult to apply to Palaeozoic fossils. The sponge described here appears to provide an exception to this pattern.

The extant Rossellidae are characterised by a combination of several distinctive features. They are included within the Lyssacinosida, an order consisting of three living hexactinellid families that have hexaster-based microscleres and unfused spicular skeletons. The other two families are the Euplectellidae and Leucopsacidae, the latter being the sister-group of Rossellidae (Dohrmann et al. 2013). The rossellids are characterised particularly by the presence of unique hypodermal pentactine prostalia (sometimes referred to as supradermal, as discussed by Brückner 2006), and reduction of many of the choanosomal hexactins to diactins. In extreme cases the lateral rays of the prostalia form a prominent veil over the body surface, a structure that is entirely distinctive in modern or fossil hexactinellids (Mehl 1992, Tabachnick 2002, Brückner \& Janussen 2005). The Rossellidae also have a characteristic skeletal architecture composed of bundles of diactins and other spicules interwoven into an irregular mesh (see examples in Tabachnick 2002). A distinct dermal layer of much smaller spicules is almost always present. This type of architecture is common among Lyssacinosida, but very different to most early Palaeozoic sponges, which are based on much more regular reticulate skeletons (usually of a single layer) and possess morphologically consistent body forms. There are thus sufficient preservable skeletal features to make the Rossellidae, or at least the wider Lyssacinosida, readily recognisable as fossils, even in the absence of diagnostic microscleres.

Molecular clock analyses currently imply an origin of crown-group Rossellidae around $220 \mathrm{Ma}$, and separation of the Rossellidae from Leucopsacidae at around $300 \mathrm{Ma}$ (Dohrmann et al. 2013). The oldest known fossil rossellids, from the Upper Cretaceous ( $\sim 88 \mathrm{Ma}$ ) of Bornholm (Brückner \& Janussen 2005), are consistent with that hypothesis. The term "rossellimorph" has been widely applied (e.g. Mehl 1992, Mehl et al. 1997, Li et al. 2015) to early Palaeozoic sponges that possess dermal pentactins but lack any specific diagnostic features of the Rossellidae. The rossellimorphs represent an informal, paraphyletic group of hexactinellid sponges (Krautter 2002) that may fall into the crown group or stem group of Hexactinellida, or potentially even the stem group of Silicea (Botting \& Muir 2018). The term is therefore primarily descriptive, and is not useful in discussions of precise phylogenetic position, as we are attempting here.

Suggestions that the Late Ordovician sponges Solusrectus and Hemidiagoniella represented the stem group of Rossellidae (Botting 2004a) were rejected by Dorhmann et al. (2013) on the grounds that they were much older than molecular clock results allowed: those results predict divergence of the Rossellidae from the Leucopsacidae at around $300 \mathrm{Ma}$, near the Carboniferous-Permian boundary. Irrespective of that argument, the Ordovician taxa also lacked diagnostic rossellid features, and should now be considered part of the 'Rossellimorpha', probably close to the base of the Lyssacinosida. The presence of a convincing stem-group rossellid in the Hirnantian (444 Ma) would therefore be extremely surprising, and requires a careful assessment of the characters available. This paper aims at a balanced discussion of how apparently diagnostic characters are used to interpret affinity in a difficult and relatively poorly-known fossil group.

\section{Geological background and palaeoenvironment}

The Anji Biota of Zhejiang Province, South China, is preserved within a basinal region with a complex interpretational history but probably representing a failed Precambrian rifting event that was further accentuated by Late Ordovician tectonism to the south (Zhang et al. 2007, Xu et al. 2016). This foreland basin or Kwangsian synorogenic basin lies between the Cathaysian Oldland to the southeast and the Yangtze Platform to the northwest, with most of the sediment input originating from Cathaysia. High sedimentation rates and thick sandstone deposits characterise the Hirnantian lowstand, with the Anji Biota preserved in a 10-m-thick black mudstone interval within the largely sandstone Wenchang Formation deposited during the post-glacial transgression in the mid to upper Metabolograptus persculptus Biozone (Botting et al. 2017a). This mudstone interval is exposed in several sections across a distance of $10 \mathrm{~km}$ (Fig. 1), with articulated sponges preserved in all sections. The central parts of most sections contain the darkest-coloured and finest-grained sediment intervals, which are also the richest sponge-bearing horizons, and are presumed to represent the maximum water depth. There are differences in the preserved faunas and taphonomic signatures between sections, with more condensed, graptolite-rich grey siltstones that are found in the basal and upper parts of the fossiliferous interval yielding only articulated skeletons of a relatively small range of taxa (see Botting 
Figure 1. Map of the Anji region within China (including small scale inset, upper left), and the locations of the three sections yielding the new species described here (inset, upper right). Localities: ZWK - Zhuwukou (30³0.507' $\left.\mathrm{N}, 119^{\circ} 22.712^{\prime} \mathrm{E}\right)$; SGS - Shangangshan $\left(30^{\circ} 35^{\prime} 48.64^{\prime \prime} \mathrm{N}, 119^{\circ}\right.$ $\left.27^{\prime} 05.62^{\prime \prime} \mathrm{E}\right)$; TFC - Tianfucun $\left(30^{\circ} 38.215^{\prime} \mathrm{N}, 119^{\circ} 28.824^{\prime} \mathrm{E}\right)$. For lithological logs of these sections, refer to Botting et al. (2017a).

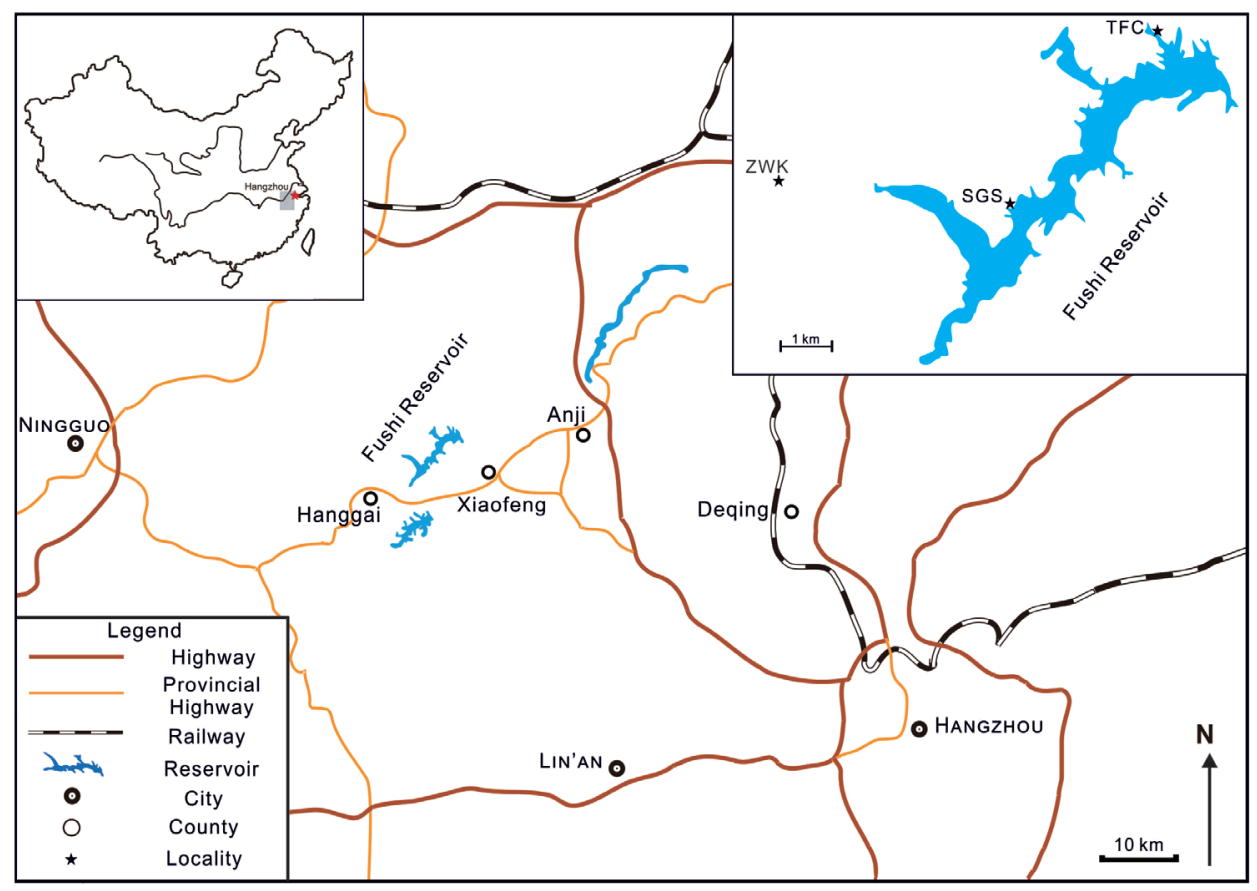

et al. 2017a). The most common sponge species in the deepest-water, black mudstone sediments are widespread across all sections, implying broad ecological continuity. Environmental changes through and between sections account for some of the faunal differences observed between beds, but much of the patchy distribution of rarer taxa probably illustrates original ecological variability.

Precise water depth for the deposits at this time is difficult to establish, but some indication can be worked out. Some sections show a basal unit of green mudstone below the sponge-bearing black mudstone, which yields a shallow-water Aegiromenella Fauna and algal fragments. This assemblage may have been transported significantly down-slope (although it was not deposited by turbidity currents), but as it contains poorly-preserved algal remains and burrows, it appears to have originated in relatively shallow water, typical of the Hirnantia faunas in China generally (Zhan et al. 2010). If there was minimal transport, this can be assumed to reflect a water depth of around $50-150 \mathrm{~m}$. The sponges lived in deeper conditions, but assuming a total eustatic sea-level rise of around $70 \mathrm{~m}$ (Zhang \& Barnes 2002) to $100 \mathrm{~m}$ (Armstrong \& Harper 2014) after the Hirnantian glaciation, and excluding very rapid local tectonic movements, the environment represented by the sponge community was probably in the depth range of at least 100-250 m. However, if the brachiopod assemblage was transported substantially down-slope, perhaps in a single event, then this estimate would increase accordingly. Overall, $100-150 \mathrm{~m}$ should be regarded as the minimum water depth for the sponge community; up to several hundred metres is theoretically possible in the presence of extremely steep bathymetry, but such high values are probably unreasonable.

Current alignment of entire sponges (Botting et al. 2017 a, fig. 2k) indicates some benthic water movement during deposition, but the presence of undisturbed lamination and scarcity of recognisable grading indicates burial under relatively gentle turbid water flows. The absence of obvious laminar truncation or nondeposition surfaces suggests continuous but sometimes elevated sedimentation, rather than discrete events. This is consistent with deep-water deposition from nearcontinuous nepheloid layers (fallout from suspension through flocculation of clay particles), rather than benthic, gravity-driven turbidity currents.

Oxygenation levels are presumed to have been low for the sponge-rich interval, due to the absence of trace fossils and almost all benthic body fossils aside from sponges. Such an anomalously high abundance and diversity of sponges in a low-oxygen environment is also recorded in the lower Cambrian Hetang Formation of South China (Xiao et al. 2005), which is regarded as having been deposited under largely anoxic conditions based on geochemical analyses (Zhou \& Jiang 2009). Pi et al. (2013) presented similar interpretations of widespread euxinia through the lower Cambrian, sponge-rich black mudstones of South China. Although sponges can tolerate unusually low-oxygen conditions of $0.5-4 \%$ present atmospheric levels, including temporary anoxia through most of their tissues (Mills et al. 2014), prolonged anoxia would presumably not have been survivable 
due to the need for respiration. Overall, the Anji Biota sponges inhabited a low-oxygen, dark sea floor with high sedimentation rate and weak to moderate benthic currents associated with rapid sediment input.

Institutional abbreviations. - All specimens are deposited in the Nanjing Institute of Geology and Palaeontology, Nanjing, China, with the prefix NIGP.

\section{Systematic Palaeontology}

Class ?Hexactinellida Schmidt, 1870

Remarks. - Various features of the new sponge described here indicate a specific affinity to one family of $\mathrm{He}$ xactinellida, and assignment to the class must form the working interpretation. However, given the unexpectedly early date, alternative interpretations are also considered (see Discussion). If the apparent diagnostic features at family level are convergently derived from a different hexactin-bearing ancestor (see Botting \& Muir 2018), then the sponge may instead represent a much earlier branch, perhaps within the stem group of Hexactinellida, or even the stem group of Silicea. As such, assignment to the Hexactinellida and other higher taxa (Lyssacinosida, Rossellidae) is not yet certain.

Order ?Lyssacinosida Zittel, 1877

Family ?Rossellidae Schulze, 1885

\section{Genus Matteolaspongia gen. nov.}

Type species. - M. hemiglobosa sp. nov.

Etymology. - From the Latin matteola, a mace or mallet, in reference to the distinctive marginalia and prostalia.

Diagnosis. - Globose to bowl-shaped reticulosans with osculum surrounded by long fringe of robust hypodermal pentactine prostalia, with single long ray embedded in body wall, and remaining rays reduced to stubs; finer, radially-directed similar pentactins (some reduced to monaxons) embedded within and project from body walls; reticulate inner layer, choanosomal spiculation finer and less regular, with hexactin-based spicules (often reduced to monaxons) in random arrangement within loose tracts.

Remarks. - Several closely-related sponges from the Anji Biota are potentially included in this genus, which has no close counterparts among described taxa. No other described taxa except for Mesozoic and Cenozoic undoubted rossellids share the hypodermal pentactine prostalia or the particular arrangement of the body wall spicules. The extreme reduction of the lateral rays of the marginalia and prostalia is uncharacteristic even of modern rossellids, although ray reduction generally is common within the body wall spiculation of that group. A similar degree of reduction of five rays is present in dermal hexactins of Thoracospongia Mehl, 1996, but in this case the remaining, grossly inflated (rather than extended) ray is believed to be directed outwards. The ray reduction in Thoracospongia therefore relates to different rays, and the sixth ray is also present; it is therefore not homologous with the current material.

\section{Matteolaspongia hemiglobosa sp. nov.}

Figures 2, 3

Holotype. - NIGP168221 (larger prepared specimen in centre, marked ' $H$ ': complete, well-preserved specimen in slightly oblique compression; from locality Tianfucun, Zhejiang Province, China; Wenchang Formation (middle to late M. persculptus Biozone, Hirnantian).

Paratypes. - NIGP168222 (cluster including largest known examples); NIGP168223 (slab with multiple specimens in different weathering stages, from locality Zhuwukou); NIGP168224 (small group of weathered specimens with good spicule detail); NIGP168225 (small individual in lateral view); NIGP168226 (two partial unweathered specimens); NIGP168227 (large group of weathered sponges with locally good spicule preservation); NIGP168228 (small cluster of partial unweathered specimens with clear body wall architecture); NIGP168229 (small partial unweathered specimen, from locality Zhuwukou); NIGP168230 (cluster of weathered and unweathered specimens). All from type locality Tianfucun unless stated; Zhuwukou represents the same horizon as Tianfucun in the area.

Figure 2. Matteolaspongia hemiglobosa gen. et. sp. nov.; A - holotype NIGP168221, overall view with additional smaller specimen at upper right; B - NIGP168228, two partial unweathered specimens, showing reticulation of body wall with thinner, non-spiculate areas between skeletal tracts; C - NIGP168225, small specimen in profile view; D - NIGP168222, slab showing largest known individuals, with complete specimen at upper right, and larger incomplete specimen at upper left; F - NIGP168222, detail of oscular fringe, with boxed area enlarged to right; G - NIGP168222, detail of lateral prostalia on upper left side of sponge, with supradermal pentactinal cross arrowed; H - NIGP168222, detail of reticulate skeleton in upper part of body wall, showing dense skeletal tracts composed of hexactins and derivatives, and very sparse, fine spicules in areas between; E - NIGP168224, part of oscular margins of two adjacent individuals, showing hypodermal pentactine marginalia (boxed spicule enlarged in inset). Scale bars: A-D, $5 \mathrm{~mm}$; E-G, $1 \mathrm{~mm}$. 

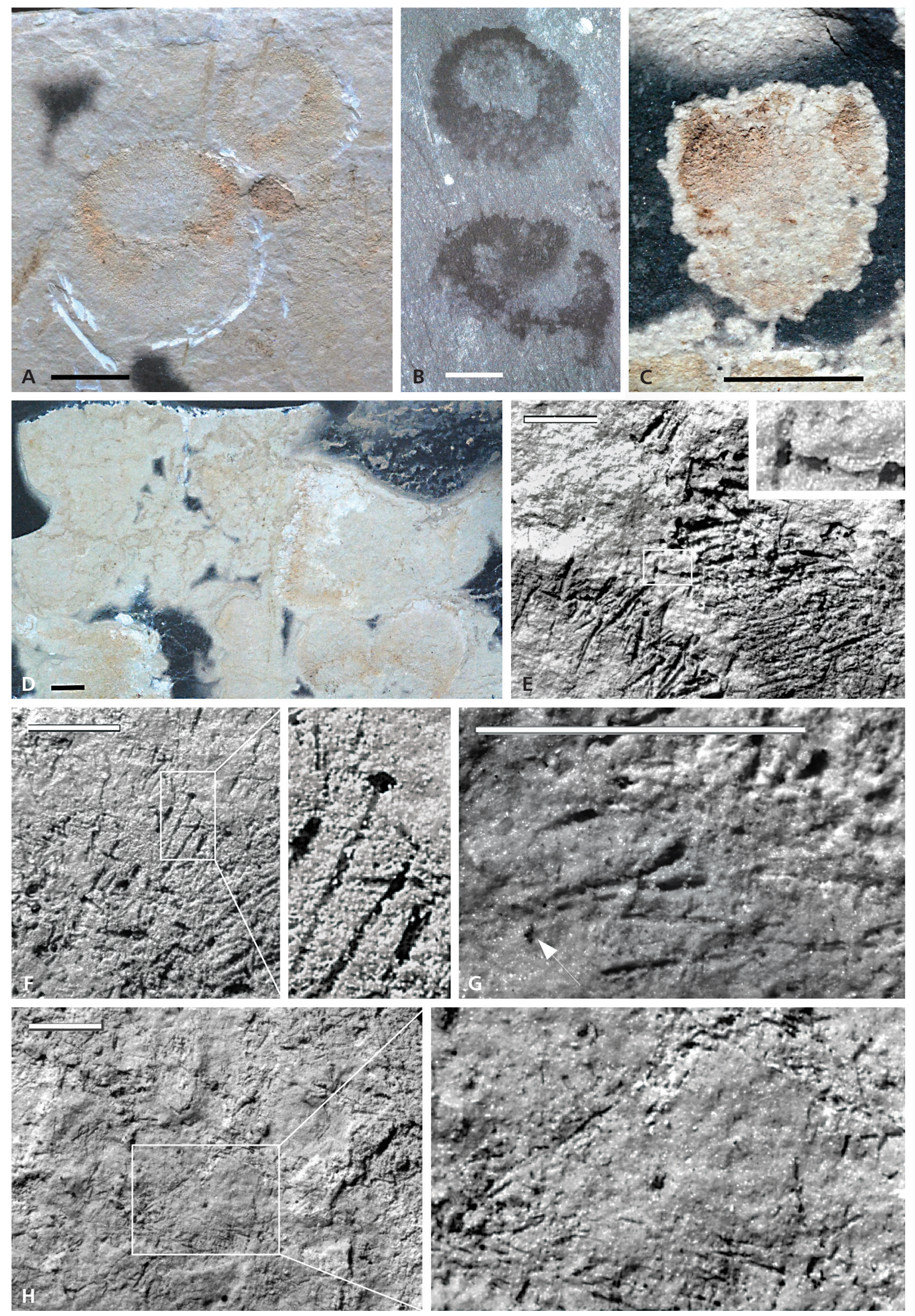
Material. - Numerous additional un-numbered specimens from the same localities, in various states of preservation, are housed in the Nanjing Institute of Geology and Palaeontology, China.

Etymology. - From the consistent, semi-globose morphology.

\section{Diagnosis. - As for genus.}

Description. - Numerous specimens, with different details visible at different weathering stages; largest spicules and overall form clearest in weathered specimens, finest spicules preserved in unweathered specimens.

Rounded, bowl-shaped sponge, typically up to $15 \mathrm{~mm}$ wide and high, with semi-circular lateral outline; exceptionally, specimens reach $25 \mathrm{~mm}$ tall and wide. Osculum slightly narrowed, with dense marginalia fringe up to $3 \mathrm{~mm}$ long in largest specimens; entire sponge slightly prolate. Body wall reticulate, with array of rounded spaces (probably internal cavities, as softtissue film present over the gaps) typically around $1 \mathrm{~mm}$ across. Skeletal zones between gaps vary substantially in width within individuals, mostly within the range $0.3-1.5 \mathrm{~mm}$.

Primary skeleton composed of small hexactins and derivatives, often with highly aberrant inter-ray angles, and reduced or missing rays; many appear to be monaxons (Fig. 3A). Maximum spicule dimensions in typicallysized specimens are ray length $0.3 \mathrm{~mm}$ and very slender ray diameter $(<0.05 \mathrm{~mm})$, with proportional size increase in largest individuals. Spicules in upper part of reticulate wall are densely arranged within soft tissues around cavities, forming locally developed bundles (Fig. 3A). In lower parts, especially near the base, spicules are more loosely organised, with no regular orientation and no obvious bundling of rays (Fig. 3B).

Arising within (or projecting through) reticulate wall are numerous fine prostalia, which increase in size and density in the upper part, and particularly around the apex where they become a dense fringe of marginalia. These superficially appear to be monaxons, but are in fact pentactins with the proximal ray greatly expanded and distal and lateral rays reduced. Normally the distal ray is absent; short (up to $0.05 \mathrm{~mm}$ long), blunt lateral rays arch away from the axis, leaving a small hollow between them; in some cases, a minute relict distal ray is present. Marginalia up to $2 \mathrm{~mm}$ long, with ray diameter $0.1 \mathrm{~mm}$; prostalia much finer than marginalia $(<1 \mathrm{~mm}$ long, diameter $<0.05 \mathrm{~mm}$ ), not clustered but denser towards apical region and sparse basally. Density of prostalia appears very variable between individuals, but this is probably at least partly taphonomic, with weathering destroying prostalia more rapidly than marginalia.

Basal region with only sparse prostalia, but somewhat denser distribution of hexactins and derivatives, with reduced gap size and density. No distinct basalia.

Discussion. - Palaeocology: Numerous specimens of M. hemiglobosa gen. et sp. nov. are available, from several different levels at different localities. However, quantitative data are not yet available, as samples were not collected as continuous bedding surfaces; analytical, multi-taxon palaeocological studies are planned in future work. The following is therefore qualitative at this stage, but nonetheless provides some useful insights.
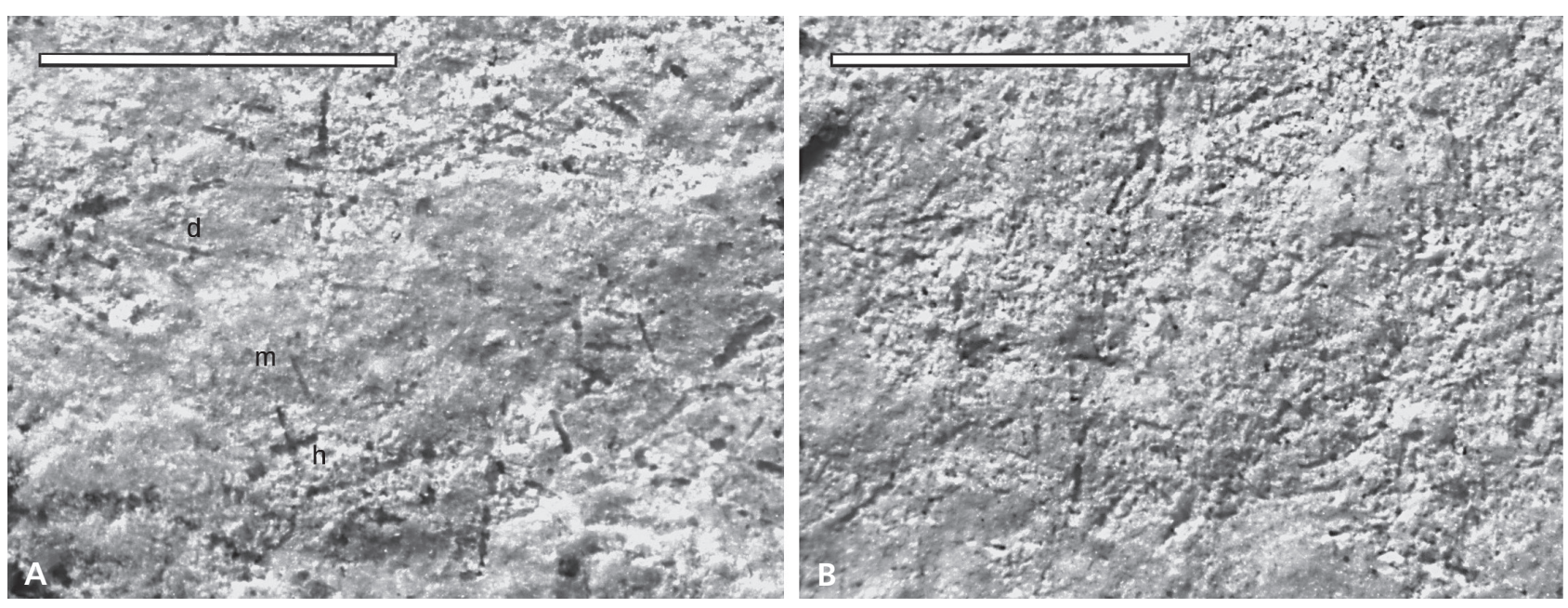

Figure 3. Comparison of skeletal wall structure of Matteolaspongia hemiglobosa gen. et. sp. nov., in upper (A) and basal (B) body wall of specimens on slab NIGP168222. A - detail of reticulate body wall in upper part, including diactine monaxons (d), modified spicules with reduced number of nonorthogonal rays (m) and hexactins (h); B - basal part of body wall, with homogeneous, non-reticulate skeleton of small hexactins and derivatives. Scale bars $1 \mathrm{~mm}$. 

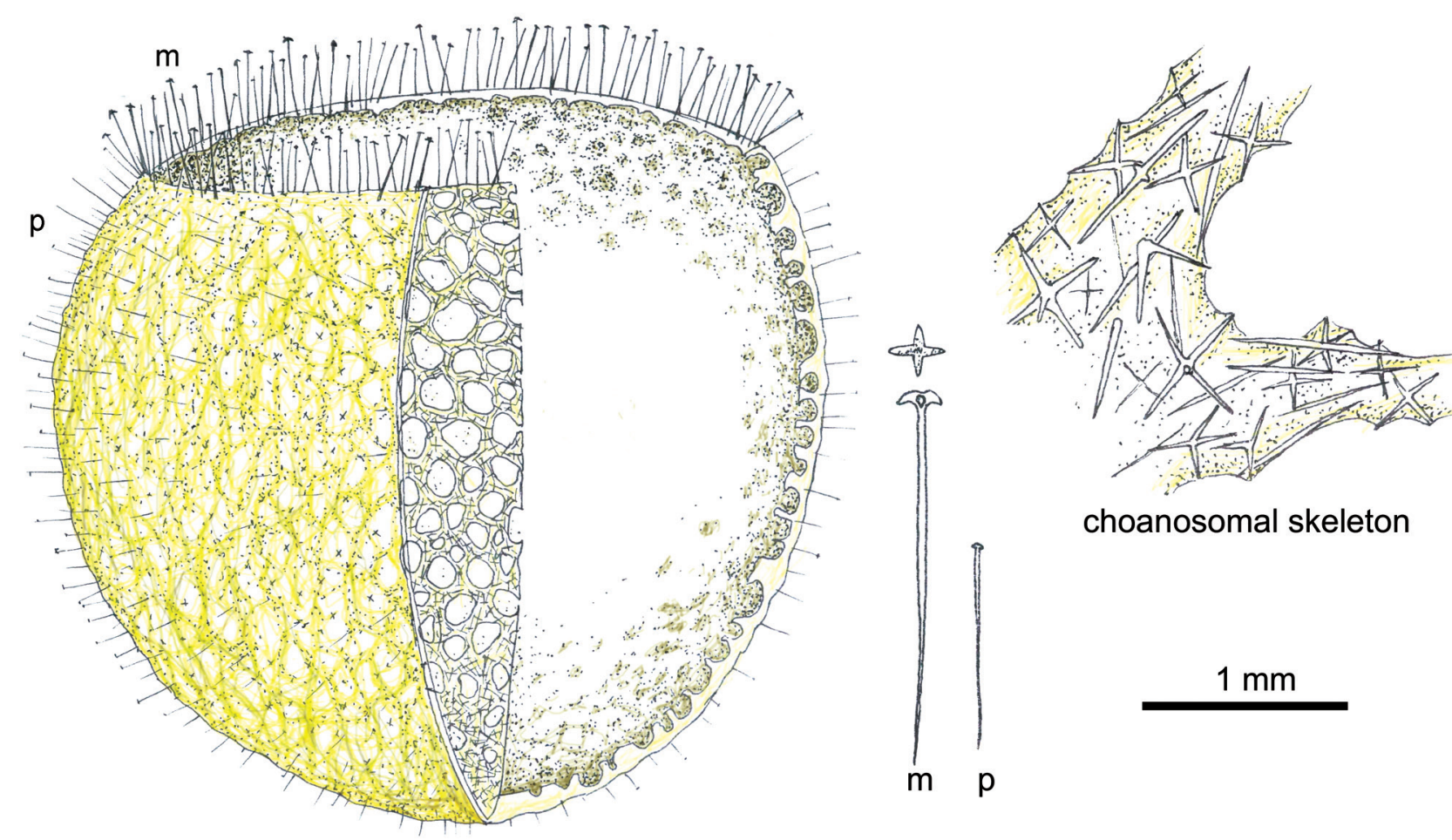

Figure 4. Cut-away reconstruction of the skeleton of Matteolaspongia hemiglobosa sp. nov., including detail of spicule organisation in choanosomal skeleton surrounding cavities, and with examples of typical hypodermal pentactine prostalia (p) and marginalia (m). Typical diameter around $15 \mathrm{~mm}$; scale bar relates to spicules and choanosomal skeleton detail.

The species is normally encountered as multiple specimens on a slab, and often as dense assemblages, potentially implying a gregarious habit. Where multiple specimens are preserved together, they are normally fully articulated but in random orientations, implying abrupt local transport rather than strictly in situ burial. Normally such associations are monospecific, with occasional examples of other taxa represented on the same surfaces, but sometimes this includes abundant diplograptid graptolites; these show no obvious preferred orientation, implying that concentration by winnowing was minimal. There is also substantial variation in sponge size within a small area, indicating that any current sorting was limited. The preserved bedding-plane assemblages, therefore, probably represent populations transported from a nearby, dense life assemblage. The precise density of these assemblages cannot be assessed, as either concentration or dilution is possible during transport, but the species almost certainly occurred as largely monospecific clusters on the sea floor.

The size range observed within each assemblage is potentially informative regarding reproductive patterns. This approach was applied to the Fezouata Biota of Morocco (Botting 2016), where species employing $r$-selection (abundant offspring with minimal assigned resources) were recognisable by distribution patterns showing mass occurrences of a single growth stage, or multiple discrete growth stages. This pattern applies also to $M$. hemiglobosa gen. et sp. nov., where many individual assemblages show size distributions within a narrow, presumed adult size range of $10-15 \mathrm{~mm}$ diameter. Numerous individual slabs with multiple specimens are limited to specimens falling within this size range. Larger individuals up to $30 \mathrm{~mm}$ diameter occur rarely, with all of the largest specimens currently known occurring on one small slab (Fig. 2D). Assuming that these do not represent a biologically distinct but morphologically similar species, this implies that most individuals did not reach their maximum size in this deposit before death by burial. The rarity of recognisable isolated spicules, or partly to completely disarticulated skeletons, further suggests that a low proportion of individuals reached their maximum lifespan such that their skeletons disarticulated on the sediment surface. Without detailed taphonomic studies, however, this may yet be an artefact related to taphonomic loss (dissolution) of spicules that were separated from soft tissues and were not pyritized due to absence of decayrelated bacteria.

Some assemblages also include individuals significantly smaller than the median size range, suggesting that regeneration occurred in situ within the community, adding to the density of the local population. The contrasting 
absence of occasional large individuals in the bedding plane assemblages suggests that initial populations were established by spatfall communities of many individuals together. In combination, this suggests that two reproductive modes were operating: mass spawning with widespread larval dispersal, allowing the initiation of new local populations, and also a more localised reproductive strategy (perhaps asexual) that provided continuity within the community. Such combinations of reproductive strategies are known in living hexactinellids, including Antarctic rossellids (Teixidó et al. 2006), in which the primary asexual reproductive mode is by budding or division. The simple growth form of the new sponge makes budding unlikely in this case, as it should be obvious in the fossils; although many specimens are overlapping in the dense assemblages, there are also many isolated specimens.

\section{Discussion}

Several features of the new sponge (reconstructed in Fig. 4) are indicative of a rossellid affinity. These include the presence of hypodermal pentactine prostalia (as both marginalia and lateral prostalia), the porous, semireticulate body wall composed of numerous fine hexactinbased spicules, and common ray reduction of hexactins to diactins. In particular, hypodermal pentactins as prostalia are a diagnostic characteristic of the Rossellidae among living taxa, although they are not present in all genera (Tabachnick 2002). The body-wall spiculation of the new species is also highly characteristic of extant Rossellidae, particularly the extensive reduction of hexactins to choanosomal or dermal diactins.

Differences from extant hexactinellids are also visible, however, most notably in the conservative and consistent body form. Most living rossellid species have a characteristic morphology, but exhibit significant variation within it, in contrast to the highly consistent semiglobose form of the new species. The modern body form also tends to be much more complex, in some cases with a stalk, and in many others with irregular, lumpy surface sculpture (Tabachnick 2002). More importantly that the body form, however, is that the skeletal architecture of modern rossellids is generally dense and fibrous (e.g. Menshenina et al. 2007), in contrast to the much more open architecture of Matteolaspongia gen. nov. The modern skeletal characteristics and body forms are also seen in the Cretaceous Rossella bromleyi Brückner \& Janussen, 2005 and other species in that assemblage (Brückner 2006).

The differences that separate Matteolaspongia gen. nov. from the living rossellids are instead broadly similar to the skeleton and body form of many early Palaeozoic reticulosans. Globose body forms were normal, for example, in the stem lineage of Demospongiae (Botting et al. 2017b), and are also characteristic of some very earlybranching sponges such as the heteractinid Eiffelia Walcott, 1920 (see also Rigby 1986, Botting \& Butterfield 2005). Variations between globose and conical ('vasiform'), with radial symmetry, are virtually ubiquitous for reticulosans, and this basic morphology is undoubtedly primitive (Botting \& Muir 2018), with complex and irregular growth forms evolving to become more normal within the Hexactinellida. This development probably occurred within the stem lineage of hexactinellida, and not as late as the stem lineage of Rossellidae, making the form of Matteolaspongia gen. nov. more typical of much earlier branches.

Prominent marginalia are not common among these early groups, but are present in a range of both simple (e.g. Dawson \& Hinde 1889) and complex (Amphispongia; see Botting 2004b) reticulosans and other hexactinbearing sponges. However, in described reticulosans, these marginalia are exclusively monaxons, or the distal rays of marginal hexactins, and are therefore likely to be convergent. Lateral prostalia are also an uncommon feature of reticulosans, but are a primary characteristic of the Asthenospongiidae (Rigby et al. 1981, Botting 2004a), where they are formed by elongated distal rays of hexactins. In Matteolaspongia gen. nov., as with the marginalia, the lateral prostalia are extruded hypodermal pentactins, which have not been recorded in any sponge group other than the Rossellidae.

The uniqueness of the rossellid-like features seen in Matteolaspongia gen. nov. dictate that assignment to the Rossellidae must be seriously considered, but the differences from crown-group genera suggest that a stemRossellidae interpretation is most plausible. The specific similarities to the Rossellidae separate the new genus from all described reticulosans, as well as from other extant hexactinellid lineages. Unfortunately, little is currently known of the morphology of the last common ancestor of rossellids with other lyssacinosidans, but a comparison with the more primitive reticulosans is consistent with a simple globose body form and less complex dermal architecture.

The balance of morphological evidence is fully consistent overall with a stem-Rossellidae interpretation, with the genus having separated after the origination of family-specific characters (diactine choanosomal spicules, hypodermal pentactine prostalia and marginalia), but before the divergence of any living genera. However, this conflicts sharply with current molecular clock estimates (Dohrmann et al. 2013) that indicate separation of Rossellidae from Leucopsacidae probably in the Permian, at around half the age of these fossils. Revision of calibration points by the discovery of new fossils 
is standard procedure, but such dramatically extended calibration points will have significant implications for deeper nodes and more basal divergence dates within Hexactinellida. Direct confirmation of the interpretation is currently prevented by taphonomic problems; in particular, distinctive microscleres would offer a precise assignment to family level (or better), but are almost never preserved as fossils within articulated sponges.

In the absence of unambiguous morphological characters with sufficient detail to preclude convergence, interpretations must rely instead on the presence of multiple independent characters all indicating the same interpretation. In this case, those characters are hypodermal pentactine prostalia, including prominent marginalia, and reduced rays on dermal and choanosomal hexactins resulting in a partly diactin-based skeleton. Additional rossellid-specific characters would be desirable for a confident interpretation, but the otherwise unique origin of the hypodermal pentactine prostalia argues against convergence. Unlike most prostalia, in which the distal ray only is extruded, the spicule centre is projected beyond the body wall. Spicule growth requires secretion by enveloping scleroblasts (Tabachnick et al. 2017), and rossellid prostalial pentactins are secreted as hypodermalia before being extruded. A similar process occurs in the secretion of basalia, such as the giant basal spicules of Monorhaphis, in which biosilicification is continued by clusters of surface sclerocytes (Wang et al. 2011); however, the Monorhaphis basalia are secreted within the body tissues, with the spicule extending upwards as the sponge grows (Wang et al. 2008) over long times scales that can exceed ten thousand years (Jochum et al. 2012). In amphidiscophorans and other lophophytous sponges (those anchored by a root tuft), the same process occurs, with the basalia secreted proximally within the body and continuously extruded (Tabachnick et al. 2017).

The process of simultaneous spicule secretion and extrusion is therefore widespread, and in cases with anchorate basalia, the axial cross is extruded first as in the hypodermal pentactins. It is therefore surprising that the Rossellidae provide the only example of hypodermal pentactine prostalia, since non-prostalial hypodermal pentactins are also normal for the Amphidiscophora (Dohrmann et al. 2017). Dohrmann et al. (2017) considered rossellid hypodermal pentactins to have evolved convergently with those of Lyssacinosida, due to their recovery of primitive fused skeletons for Hexasterophora in the output of their preferred model, but in that study polarisation using fossil taxa was not considered. Given the non-fused skeletons of all of the ancestral reticulosans, plus the existence of numerous early fossil taxa with a regular array of (presumed hypodermal) pentactins (e.g. Heminectere Botting, 2004a), it is likely that these were primitive for the Hexactinellida crown group. Transforming these into rossellid-type prostlial hypodermalia appears, for unknown reasons, to have occurred only once, and this character therefore carries significant weight as a phylogenetic marker. However, the form of these spicules, with greatly reduced lateral rays, has no obvious counterpart among living rossellid genera.

Pentactins with atrophied rays resembling the prostalia described here (but not projecting from the body wall) are also known to occur as choanosomal spicules in some amphidiscophorans (Vinod et al. 2012). Although these were probably convergently evolved, this demonstrates the problems with interpretation of apparently distinctive spicule characters. Ultimately, resolving the phylogenetic position of Matteolaspongia gen. nov. with certainty may rely on the discovery of additional taxa that bridge the gap to certain rossellids, or to another group of sponges. Nonetheless, the evidence currently supports a tentative assignment of Matteolaspongia gen. nov. to the stem group of Rossellidae.

\section{Conclusions}

Matteolaspongia hemiglobosa gen. et sp. nov., from the latest Ordovician Anji Biota of China, represents a previously unknown group of hexactinellid (or hexactinellid-like) sponges. It displays diagnostic characters (hypodermal pentactine prostalia, partly diactin-based skeleton) of the extant family Rossellidae, but differs from all known taxa in its simpler, more consistent body form, less dense choanosomal skeleton with fewer diactins, and in the extreme reduction of the distal and lateral rays of the prostalia. Morphologically, it is best placed within the stem group of Rossellidae, but convergence cannot be ruled out, and the early date conflicts with current molecularclock predictions of a Carboniferous or Permian origin for this lineage. The systematic assignment therefore remains tentative, and illustrates the interpretational difficulties relating to early hexactinellid-like taxa, especially when observations of fossils conflict with predictions based on other methods.

\section{Acknowledgements}

Research on the Anji Biota is funded by a Chinese Academy of Science (CAS) President's International Fellowship Initiative to JPB (grant number 2016VEB006), LAM (No. 2018VCB0014), and by CAS and Ministry of Science and Technology of China grants (grant numbers XDB10010100, 2017ZX05036-001-004 and 2013FY111000) to ZYD. Thanks to Xuan Ma, Xiang Fang, Junye Ma and Wenjie Li (all Nanjing Institute of Geology and Palaeontology) for assistance on fieldwork, and Longwu Wang 
(Zhejiang Geological Survey) for introducing us to some of the sites. The manuscript was improved by constructive reviews by Dorte Janussen and Radek Vodrážka.

\section{References}

Armstrong, H. \& Harper, D.A.T. 2014. An earth system approach to understanding the end-Ordovician (Hirnantian) mass extinction, 287-300. In Keller, G. \& KerR, A.C. (eds) Volcanism, impacts, and mass extinctions: causes and effects. The Geological Society of America, Special Paper 505.

Botting, J.P. 2004a. An exceptional Caradoc sponge fauna from the Llanfawr Quarries, central Wales and phylogenetic implications. Journal of Systematic Palaeontology 2, 31-63. DOI 10.1017/S147720190300110X

Botting, J.P. 2004b. A revision of the hexactinellid sponge Amphispongia oblonga Salter 1861: Not a dasycladacean alga. Scottish Journal of Geology 40, 115-118. DOI 10.1144/sjg40020115

BotTInG, J.P. 2016. Diversity and ecology of sponges in the Early Ordovician Fezouata Biota, Morocco. Palaeogeography, Palaeoclimatology, Palaeoecology 460, 75-86. DOI 10.1016/j.palaeo.2016.05.018

Botting, J.P. \& Butterfield, N.J. 2005. Reconstructing early sponge relationships by using the Burgess Shale fossil Eiffelia globosa, Walcott. Proceedings of the National Academy of Sciences of the United States of America 102, 1554-1559. DOI 10.1073/pnas.0405867102

Botting, J.P. \& Muir, L.A. 2018. Early sponge evolution: a review and phylogenetic framework. Palaeoworld 27, 1-29. DOI 10.1016/j.palwor.2017.07.001

Botting, J.P., Zhang, Y.D. \& Muir, L.A. 2017b. Discovery of missing link between demosponges and hexactinellids confirms palaeontological model of sponge evolution. Scientific Reports 7 (5286), 1-7. DOI 10.1038/s41598-017-05604-6. DOI 10.1038/s41598-017-05604-6

Botting, J.P., Muir, L.A., Zhang, Y.D., MA, X., MA, J.Y., WANG, L.W., Zhang, J.F., Song, Y.Y. \& Fang, X. 2017a. Flourishing Sponge-Based Ecosystems after the End-Ordovician Mass Extinction. Current Biology 27, 556-562. DOI 10.1016/j.cub.2016.12.061

Botting, J.P., Muir, L.A., Wang, W.H., Qie, W.K., TAN, J.Q., Zhang, L.N. \& Zhang Y.D. 2018. Sponge-dominated offshore benthic ecosystems across South China in the aftermath of the end-Ordovician mass extinction. Gondwana Research. DOI 10.1016/j.gr.2018.04.014

BRÜCKNER, A. 2006. Taxonomy and paleoecology of lyssacinosan Hexactinellida from the Upper Cretaceous (Coniacian) of Bornholm, Denmark, in comparison with other Postpaleozoic representatives. Abhandlungen der Senckenbergischen Naturforschenden Gesellschaft 564, 1-103.

BrÜCKner, A. \& Janussen, D. 2005. Rossella bromleyi n. sp.: The first entirely preserved fossil sponge species of the genus Rossella (Hexactinellida) from the Upper Cretaceous of Bornholm, Denmark. Journal of Paleontology 79, 21-28. DOI 10.1666/0022-3360(2005)079<0021:RBNSTF $>2.0$.CO;2
Dawson, J.W. \& Hinde, G.J. 1889. On new species of fossil sponges from the Siluro-Cambrian at Little Métis on the Lower St. Lawrence; including notes on the specimen by Dr. G. J. Hinde, F. G. S. Transactions of the Royal Society of Canada (section IV), Geological and Biological Sciences 7 , 31-55.

Dohrmann, M., Kelley, C., Kelly, M., Pisera, A., Hooper, J.N.A. \& ReIswig, H.M. 2017. An integrative systematic framework helps to reconstruct skeletal evolution of glass sponges (Porifera, Hexactinellida). Frontiers in Zoology 14:18, 1-31. DOI 10.1186/s12983-017-0191-3

Dohrmann, M., Vargas, S., Janussen, D., Collins, A.G. \& Wörheide, G. 2013. Molecular paleobiology of earlybranching animals: integrating DNA and fossils elucidates the evolutionary history of hexactinellid sponges. Paleobiology 39, 95-108. DOI 10.1666/0094-8373-39.1.95

Jochum, K.P., Wang, X., Venemann, T., Sinha, B., \& Müller, W.E. 2012. Siliceous deep-sea sponge Monorhaphis chuni: A potential paleoclimate archive in ancient animals. Chemical Geology 300-301, 143-151.

DOI 10.1016/j.chemgeo.2012.01.009

Krautter, M. 2002. Fossil Hexactinellida, 1211-1223. In Hooper, J.N.A. \& VAn Soest, R.W.M. (eds) Systema Porifera: A Guide to the Classification of Sponges. Kluwer Academic/Plenum Publishers, New York.

Li, L.X., Feng, H.Z., Janussen, D. \& Reitner, J. 2015. Unusual Deep Water sponge assemblage in South China-Witness of the end-Ordovician mass extinction. Scientific Reports 5(16060), 1-7. DOI 10.1038/srep16060

Mert, D. 1992. Die Entwicklung der Hexactinellida seit dem Mesozoikum. Paläobiologie, Phylogenie und Evolutionsökologie. Berliner geowissenschaftliche Abhandlungen (E) 2, 1-164.

Ment, D. 1996. Phylogenie und Evolutionsokölogie der Hexactinellida (Porifera) im Paläozoikum. GeologischPaläeontologische Mitteilungen Innsbruck 4, 1-55.

Mehl, D., Wuttke, M. \& Kotт, R. 1997. Contributions to the sponge-fauna of the Hunsrück-Slate (II) Description of a new siliceous sponge (Hexactinellida, "Rossellimorpha", fam., gen. et sp. indet.). Neues Jahrbuch für Geologie und Paläontologie Monatshefte 1997, 79-92.

Menshenina, L., Tabachnick, K.R., Lopes, D.A. \& Hajdu, E. 2007. Revision of Calycosoma Schulze, 1899 and finding of Lophocalyx Schulze, 1887 (six new species) in the Atlantic Ocean (Hexactinellida, Rossellidae), 449-465. In CustóDIo, M.R. (ed.) Porifera Research: Biodiversity, Innovation and Sustainability - 2007. Museo Nacional, Rio de Janeiro.

Mills, D.B., Ward, L.M., Jones, C., Sweeten, B., Forth, M., Treusch, A.H. \& CAnfield, D.E. 2014. Oxygen requirements of the earliest animals. PNAS 111, 4168-4172. DOI 10.1073/pnas.1400547111

Pi, D.H., Liu, C.Q., Shields-Zhou, G.A. \& Jiang, S.Y. 2013. Trace and rare earth element geochemistry of black shale and kerogen in the early Cambrian Niutitang Formation in Guizhou province, South China: Constraints for redox environments and origin of metal enrichments. Precambrian Research 225,218-229. DOI 10.1016/j.precamres.2011.07.004 
Rigby, J.K. 1986. Sponges of the Burgess Shale (Middle Cambrian) British Columbia. Palaeontographica Canadiana 2, $1-105,20$ pls.

Rigby, J.K., King, J.E. \& Gunther, L.F. 1981. The new Lower Ordovician protosponge, Asthenospongia, from the Phi Kappa Formation in central Idaho. Journal of Paleontology $55,842-847$.

Schmidt, O. 1870. Grundzüge einer Spongien-Fauna des Atlantischen Gebietes. 88 pp. Wilheim Engelmann, Leipzig.

Schulze, F.E. 1885. The Hexactinellida, 437-451. In Tizard, T.H., Mosely, H.M., Buchanan, J.Y. \& Murray, J. (eds) Report on the scientific results of the voyage of H.M.S. 'Challenger' during the years 1873-1876.

TABACHNick, K.R. 2002. Family Rossellidae Gray, 1867, 14411505. In Hooper, J.N.A. \& VAn Soest, R.W.M. (eds) Systema Porifera: A Guide to the Classification of Sponges. Kluwer Academic/Plenum Publishers, New York.

Tabachnick, K., Janussen, D. \& Menshenina, L. 2017. Chapter 2: Cold biosilicification in metazoan: psychrophilic glass sponges, 53-80. In EhrLich, H. (ed.) Extreme Biomimetics. Springer International, Cham.

Teixidó, N., Gili, J.-M., Uriz, M.-J., Gutt, J. \& Arntz, W.E. 2006. Observations of asexual reproductive strategies in Antarctic hexactinellid sponges from ROV video records. Deep-Sea Research II 53, 972-984. DOI 10.1016/j.dsr2.2006.02.008

Vinod, K., George, R.M., Phomas, P.A. \& Manisseri, M.K. 2012. Semperella megaloxea sp. nov. (Family: Pheronematidae): a new hexactinellid sponges from Andaman waters, India. Indian Journal of Fisheries 59, 33-36.

Walcott, C.D. 1920. Cambrian Geology and Paleontology IV, no. 6 - Middle Cambrian Spongiae. Smithsonian Miscellaneous Collection 67, 261-364.

Wang, X.H., Boreiko, A., Schlossmacher, U., Brandt, D., Schröder, H.C., Li, J., KaAndorp, J.A., GötZ, H., Duschner, H. \& Müller, W.E. 2008. Axial growth of hexactinellid spicules: Formation of cone-like structural units in the giant basal spicules of the hexactinellid Monorhaphis. Journal of Structural Biology 164, 270-280. DOI 10.1016/j.jsb.2008.08.005
Wang, X.H., Wiens, M., Schröder, H.C., Jochum, K.P., Schlossmacher, U., Götz, H., Duschner, H. \& Müller, W.E. 2011. Circumferential spicule growth by pericellular silica deposition in the hexactinellid sponge Monorhaphis chuni. The Journal of Experimental Biology 214, 2047-2056. DOI 10.1242/jeb.056275

Xiao, S.H., Hu, J., Yuan, X.L., Parsley, R.L. \& Cao, R.J. 2005. Articulated sponges from the Lower Cambrian Hetang Formation in southern Anhui, South China: their age and implications for the early evolution of sponges. Palaeogeography, Palaeoclimatology, Palaeoecology 220, 89-117. DOI 10.1016/j.palaeo.2002.02.001

Xu, Y.J., CAwooD, P.A. \& Du, Y.S. 2016. Intraplate orogenesis in response to Gondwana assembly: Kwangsian Orogeny, South China. American Journal of Science 316, 329-362. DOI 10.2475/04.2016.02

Zhan, R.B., Liu, J.B., Percival, I.G., Jin, J.S. \& Li, G.P. 2010. Biodiversification of Late Ordovician Hirnantia fauna on the Upper Yangtze Platform, South China. Science China Earth Science 53, 1800-1810. DOI 10.1007/s11430-010-4071-3

Zhang, S.X. \& Barnes, C.R. 2002. Late Ordovician-Early Silurian (Ashgillian-Llandovery) sea level curve derived from conodont community analysis, Anticosti Island, Quebec. Palaeogeography, Palaeoclimatology, Palaeoecology 180, 5-32. DOI 10.1016/S0031-0182(01)00421-7

Zhang, Y.D., Chen, X., Yu, G.H., Goldman, D., Liu, X. 2007. Ordovician and Silurian Rocks of Northwest Zhejiang and Northeast Jiangxi Provinces, SE China. 189 pp. University of Science and Technology of China Press, Hefei.

Zhou, C.M. \& JiAnG, S.Y. 2009. Palaeoceanographic redox environments for the lower Cambrian Hetang Formation in South China: Evidence from pyrite framboids, redox sensitive trace elements, and sponge biota occurrence. Palaeogeography, Palaeoclimatology, Palaeoecology 271, 279-286. DOI 10.1016/j.palaeo.2008.10.024

Zittel, K.A. 1877. Studien über fossile Spongien. I. Hexactinellidae. Abhandlungen der Mathematisch-Physikalischen Classe der Königlich-Bayerischen Akademie der Wissenschaften 13, 1-63. 